\title{
Genetic Structuring and Parentage Analysis for Evolutionary Studies in Grapevine: Kin Group and Origin of the Cultivar Sangiovese Revealed
}

\author{
Manuel Di Vecchi Staraz \\ Dipartimento Ortoflorofrutticoltura, Polo Scientifico, Università degli Studi di Firenze, Viale delle \\ Idee, 30, 50019 Sesto Fiorentino (FI), Italy; and UMR 1097, Diversité et Génomes des Plantes \\ Cultivées, INRA, Equipe “Génétique de la Vigne," 2, Place Viala, 34060 Montpellier, France
}

\author{
Roberto Bandinelli and Maurizio Boselli \\ Dipartimento Ortoflorofrutticoltura, Polo Scientifico, Università degli Studi di Firenze, Viale delle \\ Idee, 30, 50019 Sesto Fiorentino (FI), Italy
}

Patrice This, ${ }^{1}$ Jean-Michel Boursiquot, Valérie Laucou, and Thierry Lacombe

UMR 1097, Diversité et Génomes des Plantes Cultivées, INRA, Equipe "Génétique de la Vigne,"

2, Place Viala, 34060 Montpellier, France

\author{
Didier Varès \\ Unité Expérimentale du Domaine de Vassal, INRA, Route de Sète, 34340 Marseillan plage, France
}

\begin{abstract}
AdDITIONAL INDEX WORDs. ampelography, microsatellite, pedigree, genetic structure, Vitis vinifera
Abstract. Genetic structuring and parentage analysis were performed on a very large database comprising 2786 unique multilocus genotypes [20 nuclear simple sequence repeats (nSSRs)] of Vitis vinifera L. ssp. sativa (DC.) Hegi with a special focus on Tuscan cultivars to reveal the parentage and history of the cultivar Sangiovese, the most important cultivar of Italy. For this cultivar, the authors also analyzed clones and synonyms, investigating its genetic origin and intracultivar diversity. Known synonyms of 'Sangiovese' were confirmed and new ones were revealed with cultivars outside Tuscany. Some synonyms were invalidated, and unexpected homonyms were identified. The absence of true intracultivar variability leads to the rejection of a polyclonal origin for 'Sangiovese'. The existence of an Italian genetic pool composed of ancient cultivars including Sangiovese was demonstrated by analyzing the entire set of 2786 cultivars. Ten individuals compose the kin group of 'Sangiovese', including two offspring: 'Ciliegiolo' and 'Catarratto bianco faux'. Despite the large presence and long history of 'Sangiovese' in the Tyrrenian area, its kin group is unexpectedly composed of a majority of ancient cultivars that are largely diffused in far southern Italy, which leads to the hypothesis of a Sicilian origin for 'Sangiovese'. Analysis of the Tuscan pool revealed large kin groups for cultivars Mammolo and Garganega, demonstrating their contribution to the genetic diversification in the Tyrrenian area. This work contributes to the understanding of grapevine diversification, evolution, and history in Italy and Europe.
\end{abstract}

Despite the historical and economic importance of wine in Europe, little is known about the origin of the different grape cultivars (Vitis vinifera). Recent advances in molecular analysis are helping us understand grape evolution and history (This et al., 2006), but information in some cases is lacking, such as the case of the cultivar Sangiovese.

'Sangiovese' constitutes the basis of $12.5 \%$ of internationally known DOC (Denominazione di Origine Controllata) and DOCG (Denominazione di Origine Controllata e Garantita) wines (wines of Italy from restricted areas), and is the most important cultivar of Italy, where the area planted was 69,789 ha in 2000 (Istituto Nazionale di Statistica, 2000). Tuscany is the region where it is most cultivated [32,555 ha (Istituto Nazionale di Statistica, 2000)], but 'Sangiovese' is grown in California [2214 ha (U.S. Department of Agriculture, 2006)], in France [1564 ha (Ministère de l'agriculture et de la pêche, 2000)], and in other countries as well, but to a lesser extent.

'Sangiovese' was presumed to be an ancient autochthonous cultivar of Tuscany (Breviglieri and Casini, 1964; Calò et al.,

Received for publication 8 Aug. 2006. Accepted for publication 3 Apr. 2007. ${ }^{1}$ Corresponding author. E-mail: this@supagro.inra.fr.
2001), and according to some authors it could be an "Etruscan grape" (Fregoni, 1991; Mainardi, 2001). Mentioned first by Soderini (1590) as 'Sangiogheto', it was also painted by the famous Bartolomeo del Bimbi, artist of Medici's Court in the 17 th century (Basso, 1982). Since the beginning of the 19th century, 'Sangiovese' was cited several times (for review see Boselli, 2001). Thus, different denominations of 'Sangiovese' are diffused in historical and recent literature, such as 'Sangiogheto' or 'Sangioveto' (Boselli, 2001; Breviglieri and Casini, 1964). Through time, 'Sangiovese' has always been considered as a good-quality cultivar for wine production. No relatives of 'Sangiovese' were identified by previous analyses among the cultivars currently grown in Tuscany, nor were any genetic relationships with regional wild relatives noted (Di Vecchi Staraz et al., 2006a). However, two contrasting parentage hypotheses were published: 'Sangiovese' as offspring of 'Ciliegiolo' (Vouillamoz et al., 2006) or as a relative of 'Ciliegiolo' (Crespan et al., 2002; Di Vecchi Staraz et al., 2006a). 'Sangiovese', characterized by great genetic and morphological intracultivar heterogeneity (Vignani et al., 1996), has been suspected of polyclonal genetic origin (Filippetti et al., 2005; Scienza, 1993; Vignani et al., 2002). The 
Table 1. Allele sizes for 20 nuclear simple sequence repeats for grapevine accessions and cultivars used in this study of genetic structuring and parentage analysis.

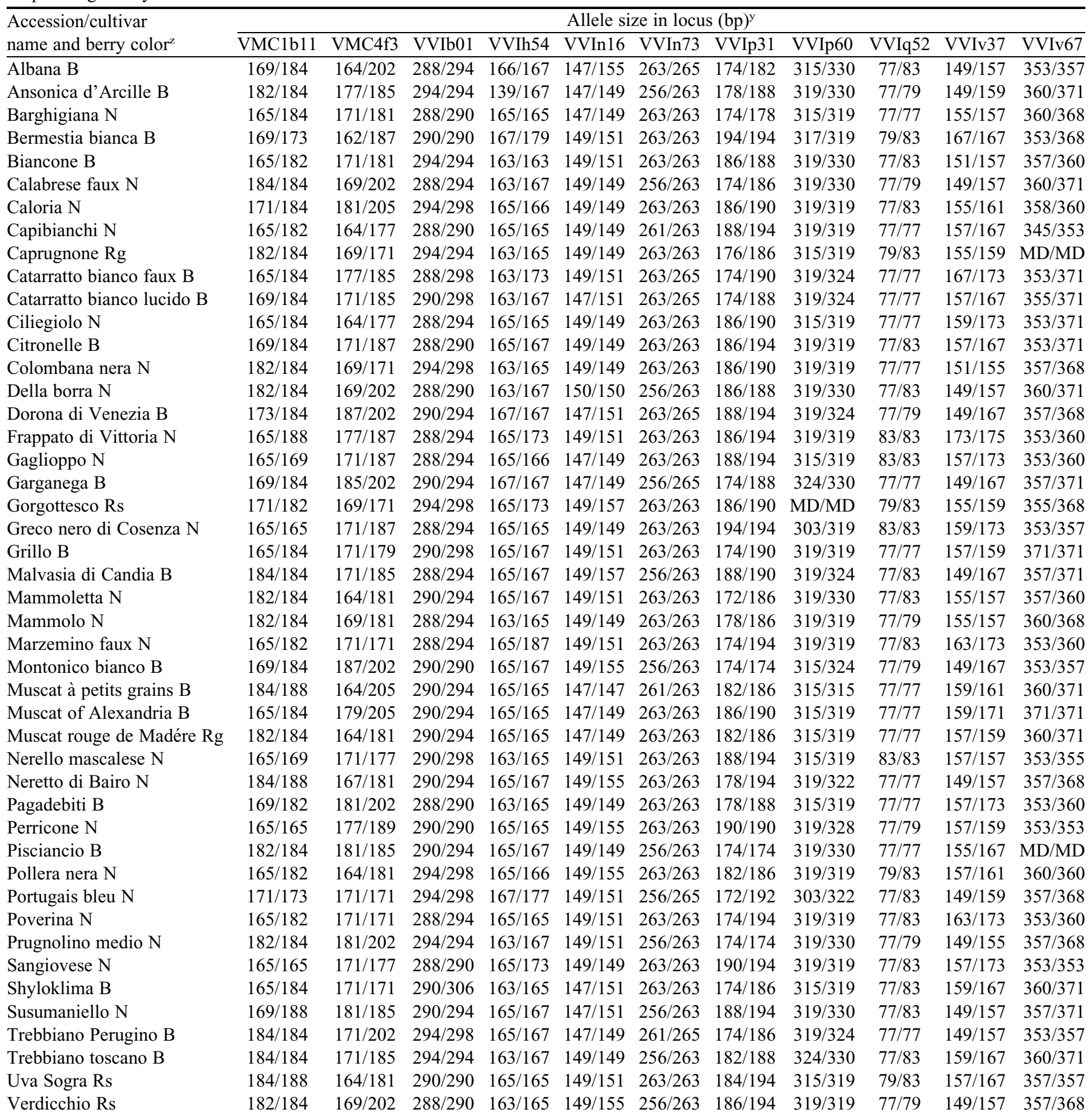

${ }^{\mathrm{z}}$ Descriptor Office International de la Vigne et du Vin (O.I.V.) 225 corresponding to berry color: N, black; B, white; Rg, red; Rs, pink (International Plant Genetic Resources Institute et al., 1997).

${ }^{y}$ For VVMD5, VVMD7, VVMD27, and VVS2, the sizes have been coded according to This et al. (2004) in relation to standard cultivars (in parentheses).

hypothesis of polyclonal origin for some ancient cultivars of $V$. vinifera provides an explanation to the intracultivar morphological variability as being derived from different seedlings (Filippetti et al., 1999; Rives, 1961). Currently, 'Sangiovese' is the cultivar with the highest number of clones registered in the Italian National Catalogue of Grapevine Cultivars (74 clones).
The use of DNA profiling based on microsatellite markers has revolutionized grape diversity analysis in less than a decade. DNA microsatellite markers [nuclear simple sequence repeats (nSSRs)] are multiallelic and highly polymorphic (for a review see Sefc et al., 2001). They have proved useful in parentage analysis (Bowers and Meredith, 1997; Bowers et al., 1999a, b; Vouillamoz et al., 2003). They are also very effective 


\begin{tabular}{|c|c|c|c|c|c|c|c|c|}
\hline \multicolumn{9}{|c|}{ Allele size in locus (bp) } \\
\hline & & & VVMD2 $27^{y}$ & VVMD28 & VVMD32 & VVMD5 $^{y}$ & VVMD7y & VVS2 $^{y}$ \\
\hline $247 / 253$ & $206 / 206$ & $240 / 254$ & 176/186 (MU1/CS2) & $233 / 235$ & $249 / 271$ & 223/229 (CF1/TR1) & 47/249 (ME2/MU2) & 131/141 (BA1/CH2) \\
\hline & & & & & & & & \\
\hline $241 / 253$ & $06 / 206$ & & & $33 / 235$ & & 225/229 (MU1/TR1) & 247/247 (ME2/ME2) & \\
\hline & & & & & & & & \\
\hline & $206 / 206$ & & & & & & & \\
\hline $247 / 247$ & $206 / 206$ & $238 / 240$ & $176 / 180$ & $/ 247$ & & $223 / 225$ & 247/253 (ME2/SU2) & \\
\hline $241 / 253$ & $206 / 206$ & $240 / 262$ & 186/191 & $235 / 235$ & & $223 / 229$ & 239/249 (CF1/N & 131/149 (B \\
\hline $241 / 241$ & $212 / 215$ & $238 /$ & $182 / 186$ & & & & & \\
\hline & & & & & & & & \\
\hline & $206 / 212$ & & & & & CF1) & & \\
\hline $241 / 247$ & $206 / 206$ & $254 / 254$ & $176 / 176$ & & & & $239 / 249$ & \\
\hline $241 / 263$ & $212 / 215$ & 240 & & & & & & \\
\hline $247 / 247$ & $206 / 210$ & 238 & & & & & $239 / 239$ & \\
\hline 53 & $206 / 210$ & & & & & & & \\
\hline & & & & & & & & \\
\hline & $206 / 206$ & & & & & & & \\
\hline $241 / 2$ & $206 / 206$ & & & & & & & \\
\hline $241 / 2$ & $206 / 206$ & 240 & & & & & & \\
\hline $247 / 247$ & $206 / 206$ & 240 & & & & & 2) & \\
\hline & & & & & & & & \\
\hline $241 /$ & $212 / 2$ & & & & & & & \\
\hline 63 & $206 / 2$ & 248 & & & & & 24 & \\
\hline & $206 / 206$ & & & & & & & \\
\hline & & & & & & & & \\
\hline & & & & & & & & \\
\hline & & & & & & & & \\
\hline & & & & & & & & \\
\hline & & & & & & & & \\
\hline & & & & & & & & \\
\hline & & & & & & & & \\
\hline & $206 /$ & & & & & & & \\
\hline & 206/206 & & & & & & 2) & \\
\hline & & & & & & & & \\
\hline & $206 / 2$ & & & & & & & \\
\hline & & & & & & & & \\
\hline & & & & & & & & \\
\hline & & & & & & & & \\
\hline & & & & & & & & \\
\hline & & & & & & & & \\
\hline & & & & & & & & \\
\hline & & & & & & & & \\
\hline & & & & & & & & \\
\hline & $206 / 206$ & $240 / 254$ & 176/188 (I & $235 / 257$ & $249 / 251$ & 223/234 (CF1/MU2) & 249/253 (MU2/SU2) & 131/153 (BA1 \\
\hline & & & & & & & & \\
\hline & & & & & & & & \\
\hline & & & & & & & & \\
\hline
\end{tabular}

for grape cultivar genetic characterization (Aradhya et al., 2003) and authentication (This et al., 2006).

'Sangiovese' has an ancient documented history, a high intracultivar diversity (Filippetti et al., 2005; Vignani et al., 2002), and occupies a large amount of acreage in Italy. It is therefore a good example to infer the history and evolution of enology and viticulture in Europe. We have thus decided to investigate the 'Sangiovese' case using nSSRs. For this purpose, 82 accessions and cultivars from the collection of the University of Florence (Italy), and nine clones of 'Sangiovese' and 2704 accessions from the Institut National de la Recherche Agronomique (INRA) Vassal grape collection (Institut National de la Recherche Agronomique, 2004) were analyzed using $20 \mathrm{nSSR}$ markers. 
The current study proposes 1) to characterize the molecular variability of 'Sangiovese', 2) to search for parentage and identify the kin group of 'Sangiovese', and 3) to extend the analysis to genetic structuring with the potential to distinguish cultivars of common ancestry and those related to 'Sangiovese' (M. Di Vecchi Staraz, unpublished data; Schaal et al., 1998).

\section{Materials and Methods}

Plant material and microsatellite analysis. The study is based on $2704 \mathrm{~V}$. vinifera unique genotypes from the Domaine de Vassal INRA grape repository (France) and 82 from the grape repository of the University of Florence, Italy. We also analyzed six official registered clones of 'Sangiovese' and three clones afferent to 'Prugnolo gentile'. The final database (2786 unique multilocus genotypes) includes individuals deriving from 38 countries (especially France, but Italy and Spain are also well represented). Tuscany, the region of presumed origin of 'Sangiovese', is well represented by more than 90 cultivars and accessions. All material analyzed was previously selected and identified by ampelographic study to guarantee whether genetic samples were true to type. Seventy-eight individuals are presented in more detail in this work. Cultivars (official registered name) are presented with abbreviation "cv." and individuals from repository are presented with repositories accession denomination preceded by "ac." Some accessions could have the same denomination as cultivars, but they are simply homonyms. The accessions Calabrese faux, Catarratto bianco faux, Marzemino faux, and Montepulciano faux analyzed in our study therefore do not correspond to their homonymous official registered cultivars. Berry color $(\mathrm{N}$, black; B, white; Rg, red; Rs, pink) follows the denominations of cultivars and accessions [descriptor Office International de la Vigne et du Vin (O.I.V.) 225 (International Plant Genetic Resources Institute et al., 1997)]. DNA extraction, polymerase chain reaction amplification, sequencing, and detection of polymorphisms were performed according to Lacombe et al. (2007) with slight modifications: $180 \mu \mathrm{L}$ buffer AP2 instead of $130 \mu \mathrm{L}$ and $10 \mathrm{~min}$ of centrifugation instead of $5 \mathrm{~min}$. All material was analyzed in the same laboratory using 20 microsatellite loci (nSSR): VVMD5, VVMD7, VVMD21, VVMD24, VVMD25, VVMD27, VVMD28, VVMD32 (Bowers et al., 1996, 1999b); VVIn16, VVIv67, VVIv37, VVIq52, VVIp60, VVIh54, VVIb01, VVIn73, VVIp31 (Merdinoglu et al., 2005); VVS2 (Thomas and Scott, 1993); and VMC1b11, VMC4f3 (Vitis Microsatellite Consortium). Codification of data for VVMD5, VVMD7, VVMD27, and VVS2 was performed according to This et al. (2004). To confirm particular parents, additional genetic characterization was performed using 18 complementary mapped nSSR loci (Adam-Blondon et al., 2004; Merdinoglu et al., 2005).

DAta ANALysis. Parentage analyses and handling of the data set were performed using FaMoz software (BIOGECO INRA, Bordeaux, France). We authorized a discrepancy of three loci, at most, to cover both possible data errors (Ewen et al., 2000), null alleles (Dakin and Avise, 2004), and clonal mutations as previously described (Vouillamoz et al., 2003). Cumulative likelihood ratios (CLRs) for proposed parent pairs and their 95\% upper confidence limits were calculated according to Cavalli-Sforza (1965) with a homemade Excel (Microsoft, Redmond, WA) macro. Dissimilarities [simple matching genetic distance (Bowcock et al., 1994)] were calculated by DarWin statistical software (version 5.0.1; Center International de Recherche Agronomique pour le Développement, Montpellier, France) based on multilocus genotype data of selected cultivars. Finally, a structuring analysis was performed with Structure software (version 2.1; J.K. Pritchard, University of Chicago, Chicago), on the data set of 2786 unique multilocus genotypes. The number of populations was estimated to be five $(\mathrm{k}=5)$ by simulations. We set 500,000 as the burning period length and the number of Markov chain Monte Carlo repetitions after burning as suggested by Pritchard et al. (2000), and used the admixture model because of the grape mating system and biology.

\section{Results}

The 10,000 simulated pairs performed by FaMoz for parentage analysis identified a $\log$ of the odds ratios (LOD) score threshold of eight for assessing a potential parent pair with 20 nSSRs. Based on this threshold, only pairs with LOD scores more than 8 were considered as valid with the current data set. The cumulated exclusion probability reached $99.99 \%$ for a single parent with the 20 loci, $100 \%$ for paternity with 11 loci, and $100 \%$ with only six loci for parent pairs. The list of the unique genotypes involved in the final analyses, along with their allele sizes, is presented in Table 1.

Clones and Synonyms of 'SAngiovese'. All nine clones of cv. Sangiovese N and cv. Prugnolo gentile N analyzed had the same genotype (Table 2). Twelve of the 23 supposed synonyms (Table 2) presented the same genotype of 'Sangiovese' (Table 1). Furthermore, we identified three cultivars from outside Tuscany: ac. Guarnacciola $\mathrm{N}$ from Campania in the south of Italy, ac. Tabernello $\mathrm{N}$ from Italy, and ac. Toustain $\mathrm{N}$ from Algeria, which presented the same profile as 'Sangiovese' (data not shown).

INCORRECT ASSIGNMENTS TO 'SANGIOVESE'. Eight individuals generally considered as synonyms of 'Sangiovese' presented profiles differing from 'Sangiovese', three of which are homonyms (Table 2). Accession Brunellone N, ac. Riminese nero N, and ac. Sangiovese polveroso Bonechi N shared the genotype of cv. Ciliegiolo N, whereas ac. Dolcetto precoce N has the same genotype as cv. Portugais bleu N. Similarly, ac. Sangiovese forte $\mathrm{N}$ and ac. Verdea B shared the same genotype, different from 'Sangiovese' and are original. The ac. Calabrese faux $\mathrm{N}$ has an original genotype. It is, furthermore, a probable offspring of the cross cv. Mammolo N by cv. Garganega B $\left(\right.$ LOD score $=42.44,20 / 20$ loci consistent, $\left.C L R=1.65 \times 10^{14}\right)$. Finally, ac. Martinetti $\mathrm{N}$ also has an original profile, different from 'Sangiovese' and shared at least one allele on 19 loci [one missing data point $(\mathrm{MD})]$ with $\mathrm{cv}$. Citronelle $\mathrm{B}$ (LOD score $=$ 19.76).

Authentication of Other Italian Cultivars Related to 'SAngiovese'. On the basis of the 20 nSSRs, we identified synonyms in the Vassal and Florence collections for 17 cultivars analyzed in this work (Table 3). All these proposed synonyms were confirmed by ampelography. For instance, we found several synonyms between Tuscan cultivars and three major Corsican cultivars: Sciaccarello N (= Mammolo N), Pagadebiti $\mathrm{B}$ (= Biancone $\mathrm{B}=$ Livornese Bianca $\mathrm{B})$, and Riminese B (= Albana B). One of the most diffused and ancient Italian cultivar, Garganega, has synonyms (Grecanico dorato B and Malvasia de Manresa B) grown in the south of Italy. Other important cultivars such as cv. Muscat blanc à petit grain or cv. Muscat of Alexandria (Muscat d'Alexandrie) presented very 
Table 2. Grapevine clones, accessions, or cultivars with nuclear simple sequence repeat profiles identical to cv. Sangiovese (synonyms) or different from 'Sangiovese' (incorrect synonyms), sharing profiles with other cultivars (alternative synonyms).

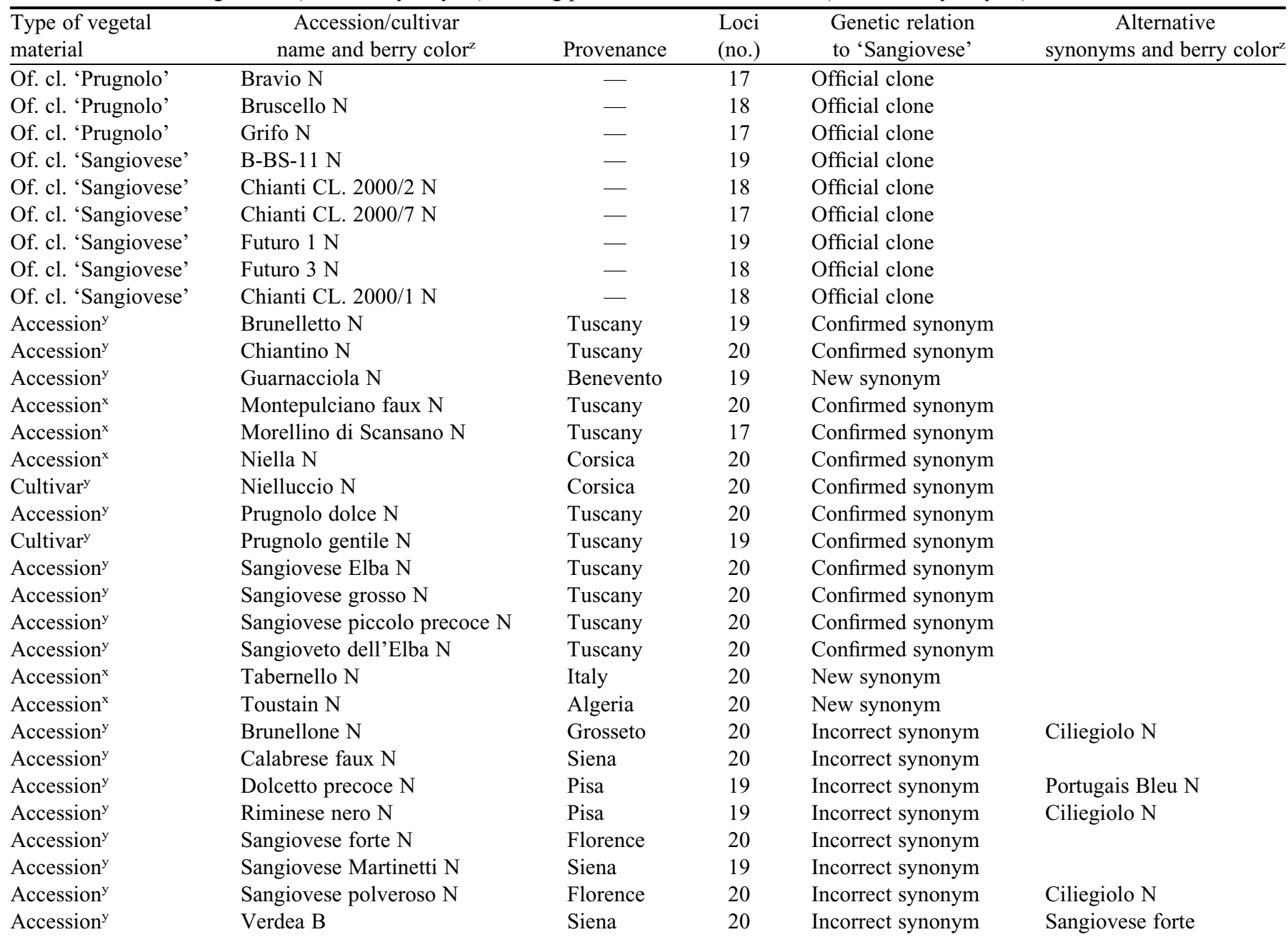

${ }^{\mathrm{z}}$ Descriptor Office International de la Vigne et du Vin (O.I.V.) 225 corresponding to berry color: N, black; B, white; Rg, red; Rs, pink (International Plant Genetic Resources Institute et al., 1997).

${ }^{\mathrm{y}}$ Grape from University of Florence repository.

${ }^{x}$ Grape from Institut National de la Recherche Agronomique repository.

Of. cl., official registered clone.

high numbers of synonyms. Additional synonyms were also revealed by ampelography such as $\mathrm{cv}$. Catarratto bianco lucido equal to Cataratto bianco comune, and cv. Muscat Rouge de Madère equal to Abrostine equal to Halapi voros equal to Muscat (Greece). They need to be confirmed by SSR markers.

POSITIONING OF 'SANGIOVESE' WITHIN $\boldsymbol{V}$. VINIFERA DIVERSITY. The analysis of the data set of 2786 genotypes using Structure 2.1 software identified a group of 260 cultivars in large majority grown in the Italian peninsula (mean $\mathrm{F}_{\mathrm{st}}, 0.81$; inferred cluster range, 52.9-96.1\%). 'Sangiovese' and cv. Petit rouge $\mathrm{N}$ are the best representatives (i.e., 96.1 of inferred cluster percentage) of this group. Among the cultivars with an inferred cluster percentage to this group more than $85 \%$ were many very ancient cultivars (Fig. 1) grown in the Alpine region (cultivars Cacaboué, Cornalin, Fumin, Hibou noir, Perrier noir, Prin blanc, and Vien de nus), in northeastern Italy (cultivars Nosiola, Pattaresco, Raboso Piave, Refosco dal peduncolo rosso, and Sgavetta), in northwestern Italy (cultivars Arneis, Avarengo,
Barbera, Besgano nero, Nebbiolo, Neretto di Bairo, and Vespolina), in Emilie-Romagne (cultivars Angiola, Fortana, Forcellina, Lambrusco monterico, Montu, and Trebbiano romagnolo), in the Tyrrenian area (cultivars Albarola, Arvesiniadu, Bonamico, Caloria, Capibianchi, Ciliegiolo, Colombana nera, Genovese, Groppello gentile, Mammolo, Marzemino faux, Pollera nera, Poverina, Sangiovese forte, and Vernaccia di Oristano), in Campania (cultivars Biancolella, Falanghina, Fiano, and Forastera), and in southern Italy (cultivars Gaglioppo, Greco nero di Cosenza, and Nerello Mascalese).

Parentage analysis and 'Sangiovese' kin group. Parentage analyses was performed considering up to three discrepancies, but we only identified possible relatives of 'Sangiovese' with no discrepancies. LOD scores are indicated in parentheses after the names of the cultivars. In a few cases, only 19 loci were used because of missing data (indicated as 19 loci). Ten individuals shared at least one allele with 'Sangiovese' (Fig. 2): ac. Catarratto bianco faux B (20.96), cv. Ciliegiolo 
Table 3. Synonyms of the grapevine accessions and cultivars involved in the kingroup of grapevine cv. Sangiovese, cv. Catarratto bianco lucido, cv. Garganega, and cv. Mammolo, based on 20 nuclear simple sequence repeat profiles identified in the University of Florence and Institut National de la Recherche Agronomique repositories.

\begin{tabular}{|c|c|}
\hline Accession/cultivar name and berry color $^{2}$ & Synonyms identified (y, provenance) \\
\hline Albana $^{x}$ B & Riminese $^{\mathrm{x}}(1949$, Corsica $)$ \\
\hline Ciliegiolo $^{\mathrm{y}, \mathrm{x}} \mathrm{N}$ & $\begin{array}{l}\text { Brunellone }^{\mathrm{y}} \text { (1988, Grosseto); Foglia tonda }{ }^{\mathrm{x}} \text { (1967, Italy); Mazzèse }{ }^{\mathrm{x}} \text { (1967, Italy); } \\
\text { Riminese nero }^{\mathrm{y}}(1988 \text {, Tuscany); Sangiovese polveroso } \\
\text { (1988, Tuscany) }\end{array}$ \\
\hline Garganega $^{x} B$ & Grecanico dorato $^{x}\left(1968\right.$, Italy); Malvasia de Manresa $^{x}$ (1993, Spain) \\
\hline Greco nero di Cosenza ${ }^{x} \mathrm{~N}$ & Lagrima nera di Barlettax $(1949$, Coll. Ravaz) \\
\hline Malvasia di Candia ${ }^{\mathrm{x}}$ & Malvasia Candia ${ }^{x}(1983$, Portugal) \\
\hline Muscat à petits grains ${ }^{\mathrm{x}, \mathrm{w}} \mathrm{B}$ & 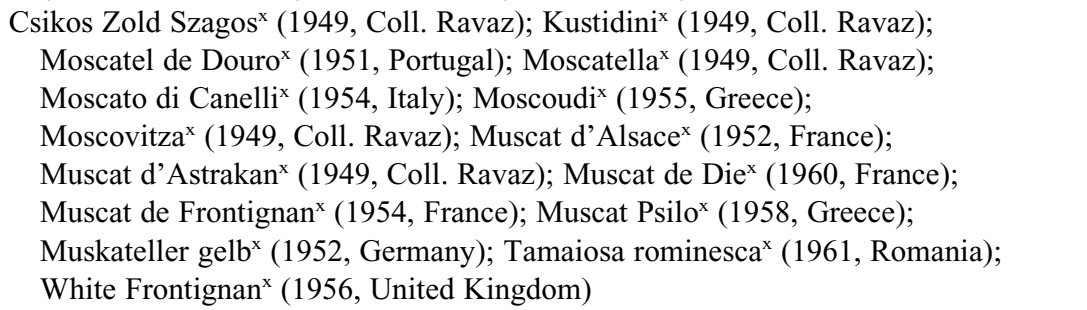 \\
\hline Muscat rouge de Madère $^{x} \mathrm{Rg}$ & $\begin{array}{l}\text { Ferral tinto }{ }^{\mathrm{x}} \text { (1949, Coll. Ravaz); Madère Vendel }{ }^{\mathrm{x}} \text { (1954, Coll. Saumur); } \\
\text { Moscatoy (1988, Tuscany) }\end{array}$ \\
\hline Nerello mascalese ${ }^{\mathrm{x}} \mathrm{N}$ & Bombino nero ${ }^{x}(1968$, Italy $)$ \\
\hline
\end{tabular}

${ }^{\mathrm{z}}$ Descriptor Office International de la Vigne et du Vin (O.I.V.) 225 corresponding to berry color: N, black; B, white; Rg, red; Rs, pink (International Plant Genetic Resources Institute et al., 1997).

${ }^{y}$ Grape from University of Florence repository.

${ }^{\mathrm{x}}$ Grape from Institut National de la Recherche Agronomique repository.

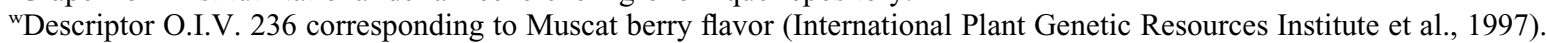

Coll., collection.

(19.8), ac. Capibianchi N (19.24), cv. Frappato di Vittoria N (17.44), cv. Gaglioppo N (15.85), cv. Nerello mascalese N (15.29), cv. Greco nero di Cosenza N (15.33), ac. Poverina N (14.89, 19 loci), ac. Marzemino faux N (14.84), and cv. Perricone N (13.31). Genetic distances between 'Sangiovese' and its 10 relatives were computed (Table 4$)$. They are all very closely related to 'Sangiovese', particularly 'Nerello mascalese' and 'Gaglioppo' ( $\mathrm{D}=0.325)$. The most distant from 'Sangiovese' are 'Perricone', 'Greco nero di Cosenza', ac. Poverina, and ac. Capibianchi. Accession Poverina and ac. Marzemino faux, sharing the same profile for 18 loci out of 20 , were further characterized with 17 additional markers. In the final analysis, they shared only 19 loci out of 35 .

We identified only one putative parent pair for 'Sangiovese' without discrepancies on 20 loci: ac. Catarratto bianco faux and 'Nerello mascalese'. The LOD score for this relationship is quite high $(38.82)$, as well as the CLR $\left(5.52 \times 10^{11}\right)$. However, we identified two discrepancies in this parentage after analysis using 15 additional markers (three MD).

Because these relatives could be parents, offspring, or half or full sibs of 'Sangiovese' (i.e., more than $50 \%$ of shared alleles on all loci), we verified their parentage with the 20 loci and 


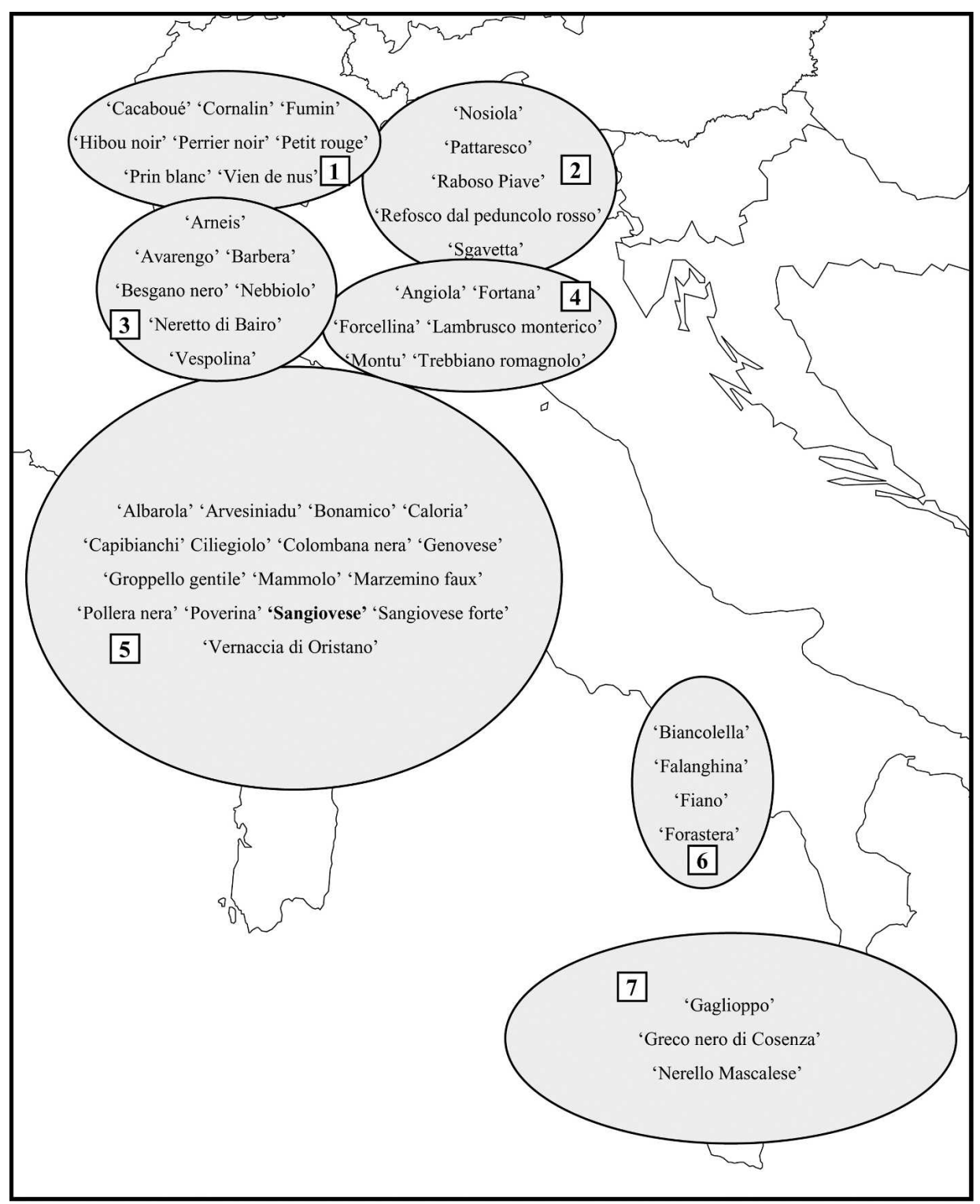

Fig. 1. Distribution of the grapevine cultivars grown in the Italian peninsula belonging to the inferred cluster of 'Sangiovese' (higher than $85 \%$ ) based on the 20 nuclear simple sequence repeats. The genetic population was identified using Structure 2.1 software (Pritchard, Chicago). The cv. Sangiovese is in bold type. 1, alpine region; 2, northeastern Italy; 3, northwestern Italy; 4, Emilie-Romagne; 5, Tyrrenian area; 6, Campania; 7, southern Italy.
IDENTIFICATION OF OTHER ITALIAN CULTIVARS RELATED TO 'SANGiOvESE'. Additional individuals were added to the 'Sangiovese' kin group through 'Catarratto bianco lucido' and 'Mammolo’ (Fig. 2). The cv. Garganega is linked to 'Sangiovese' through 'Catarratto bianco lucido'. In addition to ac. Calabrese faux, we identified two offspring of 'Garganega': ac. Dorona di Venezia B as a cross with cv. Bermestia bianca B (41.39, CLR $\left.1.15 \times 10^{14}\right)$, and cv. Susumaniello N as a cross with 'Uva Sogra' Rs (LOD score $\left.=43.39, \mathrm{CLR}=8.53 \times 10^{14}\right)$. We also identified the 'Garganega' kin group. It was composed of 12 cultivars, of which the two major cultivars Trebbiano toscano and Malvasia di Candia, largely diffused in Tuscany. Furthermore, we identified 14 cultivars including the 'Mammolo' kin group, which is linked to 'Sangiovese' by the parentage of 'Ciliegiolo' (Fig. 2). The cv. Grillo B was revealed as a cross between 'Catarratto bianco lucido' and 'Muscat d'Alexandrie' B $(\mathrm{LOD}$ score $=36.68, \mathrm{CLR}=1.29 \times$ $\left.10^{11}\right)$.

\section{Discussion}

Our results confirmed the effectiveness of SSR markers for authentication, genetic structuring, and parentage reconstruction in grape. In particular, the set of 20 markers distributed on the genome was very efficient since it allowed a high value of cumulated exclusion probabilities. Nevertheless, additional markers were necessary when several parent pairs were identified. The combination of different analyses (genetic structuring and parentage reconstruction) along with the analysis of a confirmed them with 18 additional markers. Fig. 2 presents a synopsis of the different parentage identified. For 37 markers (1 MD), the profile of ac. Catarratto bianco faux is consistent with being an offspring of 'Sangiovese' crossed with cv. Catarratto bianco lucido B (LOD score $=47.2$, CLR $=9.65 \times$ $10^{15}$ ). We also identified 'Ciliegiolo' as possible offspring of 'Sangiovese' crossed with cv. Muscat rouge de Madère N $\left(\right.$ LOD score $\left.=43.53 . \mathrm{CLR}=3.07 \times 10^{13}\right)$. This result was based on $38 \mathrm{nSSRs}$, considering the presence of a null allele for one homozygous locus among the additional markers (VMC3d8) as previously demonstrated by Vouillamoz et al. (2003). Muscat rouge de Madère $\mathrm{N}$ was itself revealed as a possible cross between 'Mammolo' and 'Muscat à petits grains' B (LOD score $=35.51, \mathrm{CLR}=1.61 \times 10^{11}$ ). These latter are consequently the grandparents of 'Ciliegiolo'. very large set of cultivars provided insight to the origin of 'Sangiovese'.

Clonal GeNetic VARIABILITY, SYNONYMS, AND INCORRECT ASSIGNMENTS To 'SANGIOVESE'. We observed the same multilocus genotype for all clones of 'Sangiovese' analyzed in this study. We also confirmed with a consistent number of nSSR loci that 'Prugnolo gentile' shares the same profile as 'Sangiovese', as observed before with fewer loci (Di Vecchi Staraz et al., 2006b; Filippetti et al., 2005). Considering the number of nSSR loci, we can establish that they are indeed the same cultivar. This case is significant, because 'Prugnolo gentile' is currently registered as a different cultivar in the Italian National Catalogue of Grapevine Cultivars, and similar cases may also be present. Such occurrences may be the result of different environmental and farming conditions. Genetic analysis 


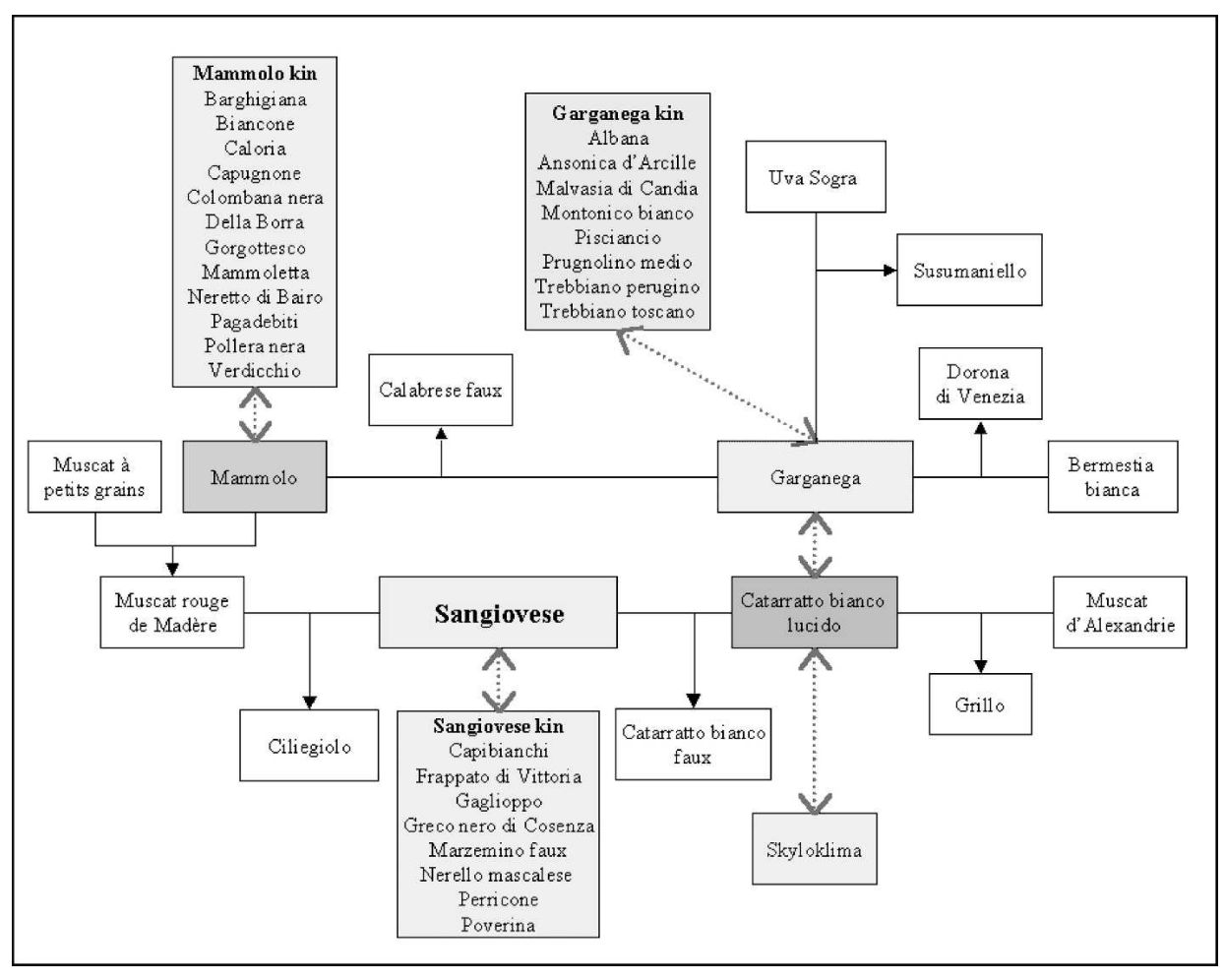

Fig. 2. Parentage and kingroup of grapevine cv. Sangiovese, cv. Catarratto bianco lucido, cv. Garganega, and cv. Mammolo based on 20 nuclear simple sequence repeat profiles. Parent pairs are connected to offspring by continuous lines and a single arrow, discontinuous lines correspond to direct parentage relationships without identified parent pairs, and shaded boxes indicate groups of cultivars/accessions sharing the same kind of parentage relationship.

allowed us to confirm 12 synonyms of 'Sangiovese', and to find three new synonyms outside Tuscany, demonstrating the presence of 'Sangiovese' elsewhere with different denominations. Eight incorrect assignments to 'Sangiovese' were identified. Three are homonyms, revealing the difficulty and importance of the correct identification of cultivars as discussed by Dettweiler et al. (2000). Furthermore, three of them showed identical patterns as 'Ciliegiolo' and can therefore be considered as synonyms of this cultivar. Morphological similarities between 'Sangiovese' and 'Ciliegiolo' are the causes of these incorrect assignments. Moreover, they have shared cultivation areas for a long time and 'Ciliegiolo' is a progeny of 'Sangiovese'. The ac. Sangiovese forte, first cited by Villifranchi (1773) and historically considered a synonym of 'Sangiovese', seems to be a distinct cultivar, but belongs to the Italian gene pool. The analysis thus illustrated the importance of synonymies between cultivars of different geographical origins. We have analyzed here the case of 'Sangiovese', but it could also be revealed for other cultivars.

Finally, we need to point out the clonal genetic homogeneity of 'Sangiovese' revealed in this work, and the absence in our data set of identified mutants, which would be expected for such an old and widespread cultivar. Further investigation should thus be conducted to cover the maximum extent of diversity in this cultivar. Nevertheless, the polyclonal origin for 'Sangiovese' as proposed by Filippetti et al. (2005), Scienza (1993), and Vignani et al., (2002) thus seems improbable. We believe that a single parent pair is at the origin of 'Sangiovese', as demonstrated for other grape cultivars (Bowers et al., 1999a). The major causes of its presumed genetic intracultivar vari- ability are its large circulation (shared with its progeny), the rich number of incorrect identifications, and the limited number of markers used in the previous studies.

Positioning of 'SAngiovese' WITHIN $\boldsymbol{V}$. VINIFERA DIVERSITY. 'Sangiovese' and its kin group were included in a genetic population composed of numerous ancient cultivars spread throughout Italy (Fig. 1). All are ancient cultivars often considered as indigenous. Among these, only 'Falanghina', 'Barbera', and 'Nebbiolo' are celebrated cultivars for wine production; the others have local diffusions all over Italy. The abundant presence of cultivars from the Alpine regions (located in Savoy and Valle d'Aosta) is noteworthy, because they are very ancient, from a very isolated geographical region, and are relics of traditional and peculiar techniques for mountain viticulture. Despite its geographical proximity, 'Sangiovese' is genetically distant from other cultivars belonging to the historical oriental grape families (Greco, Malvasia, and Muscat), largely growing in the south of Italy and from the "Calabrese' cultivars, which clustered in different groups in the structuring analysis. Similarly, we also pointed out that 'Sangiovese' has no close relatives among the most widespread cultivars of France and Spain comprised in our large data set, but has synonyms along with relatives in the Tyrrenian area (Corsica, Provence). These results presuppose the existence of an old Italian grape population that is disappearing from contemporary vineyards because of current viticulture practices.

The Parents of 'Sangiovese'. We did not identify any reliable parent pair for 'Sangiovese'. In fact, the only pair revealed with the first 20 loci involved the ac. Catarratto bianco faux, but this was later ruled out with the aid of additional markers, and because higher CLRs $\left(9.65 \times 10^{15}\right.$ vs. $\left.5.52 \times 10^{11}\right)$ and LOD scores (47.2 vs. 38.8) confirmed that 'Catarratto bianco faux' resulted from the cross 'Sangiovese' $x$ 'Catarratto bianco lucido'. The cv. Ciliegiolo has been proposed as a parent of 'Sangiovese' (Vouillamoz et al., 2006). This work clearly demonstrated that 'Ciliegiolo' is an offspring of 'Sangiovese', because we identified consistent parent and grandparent pairs with high LOD scores and high CLRs, also taking into account one null allele as demonstrated by Dakin and Avise (2004). Indeed, offspring can often be incorrectly identified as a parent (M. Di Vecchi Staraz, V. Laucou, S. Gerber, T. Lacombe, D. Varès, and P. This, unpublished data). Furthermore, historical data support our hypothesis because 'Sangiovese' was cited earlier (Soderini, 1590) than 'Ciliegiolo' (Racah, 1932). Thus 'Ciliegiolo' cannot be a parent of 'Sangiovese'.

Parent-offspring relationships are much more difficult to infer when the pair cannot be identified. Nevertheless, one parent of 'Sangiovese' could be within the identified kin group, 


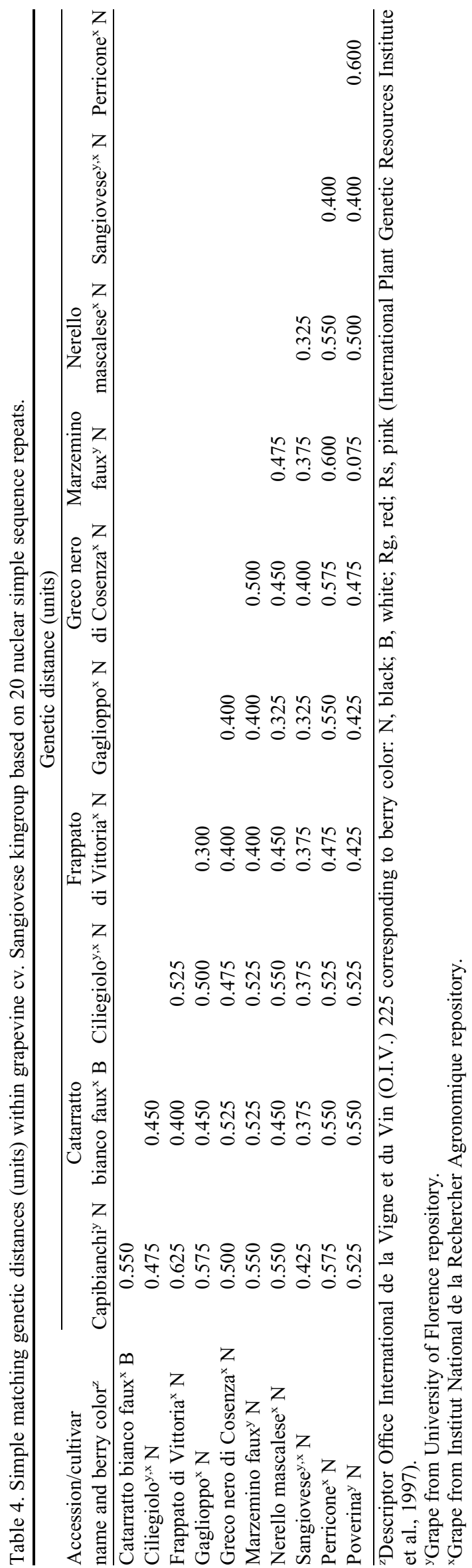

but the high genetic similarity revealed between 'Sangiovese' and its kin group rather suggests sibling relationships as demonstrated by Queller and Goodnight (1989). Two hypotheses could explain the unrevealed parentage of 'Sangiovese': 1) even though the data set analyzed is by far the most representative of the European grape genetic diversity (2786 unique nSSR profiles), the real parents of 'Sangiovese' could be extinct, or 2) both parents could simply be absent in our data set. In Calabria and Sicily more than 1600 ha and 2000 ha respectively have been classified as having unidentified grapevines (Istituto Nazionale di Statistica, 2000), so parents of 'Sangiovese' could be among these. Thus, further investigation of diversity in this part of Italy is needed.

The 'SAngiovese' KIN GROUP. The kin group is composed of two offspring with identified parent pairs, and eight close relatives (sharing at least one allele at each locus). The offspring 'Ciliegiolo' is a well-known cultivar, largely widespread in central Italy on 1420 ha (768 ha in Tuscany) and less in the southern Italian peninsula (Istituto Nazionale di Statistica, 2000). Its presumed origin has been the Iberian peninsula (Calò et al., 2001; Racah, 1932), but the parent and grandparent pairs suggest the Tyrrenian area (Corsica, Provence, Liguria, and Tuscany) as the area of origin. On the contrary, we have little information about ac. Catarratto bianco faux, which is from Sicily, as confirmed by geographical diffusion of its parent 'Catarratto bianco lucido'. Concerning the eight other relatives, five are from far southern Italy (three from Sicily and two from Calabria). Only three accessions (Capibianchi, Marzemino faux, and Poverina) are from Tuscany, but they are not registered in the Italian National Catalogue of Grapevine, almost extinct and historically unknown. Those from southern Italy are all ancient and well-known cultivars [cited first by Sestini (1774)]. Three are traditionally cultivated in Sicily: 'Nerello mascalese' belongs to the historical Nigrelli grape family, and is grown mainly in the Province of Catania as well as in Calabria [2395 ha and 107 ha, respectively (Istituto Nazionale di Statistica, 2000)]; 'Frappato di Vittoria' is essentially present in the Province of Trapani (580 ha), even if Catania is its supposed origin; and finally 'Perricone', for a long time the principal cultivar of the Province of Trapani, is now grown mainly in the Province of Palermo and Agrigento [240 ha and 197 ha, respectively (Istituto Nazionale di Statistica, 2000)]. The historical cultivars Gaglioppo and Greco nero di Cosenza are largely present in Calabria, mainly in the Province of Cosenza [3594 and 1414, respectively (Istituto Nazionale di Statistica, 2000)], but also in some central regions, as well as in Sicily, in the Province of Catania. The first was already cited as a kind of wine in the 14th century (Marescalchi and Dalmasso, 1937), and the second has numerous synonyms and homonyms resulting from the large diffusion of cultivars named Greco. These five cultivars from southern Italy are very closely related to each other. The 'Gaglioppo' from Calabria and 'Frappato di Vittoria' from Sicily are the nearest relatives within the kin group $(\mathrm{D}=0.3)$, supporting their probable full sibling relationship (M. Di Vecchi Staraz, unpublished data). These findings illustrate relations between Sicily and Calabria. In conclusion, 'Sangiovese' did not contribute to the genetic diversity in the Tyrrenian area, but 'Garganega' and 'Mammolo' are parents of many cultivars from this area (many related cultivars of 'Mammolo' were also found in Corsica), and they are therefore at the source of cultivar diversification. 
'SANGiovese' history. We collected individuals from Tuscany, which was the region of presumed origin of 'Sangiovese', but Tuscan relatives are very scarce in this work. A previous study also emphasized the absence of close genetic relationships between 'Sangiovese' and wild Tuscan vines (Di Vecchi Staraz et al., 2006a). The current presence of 'Sangiovese' in all the provinces of Sicily and in Calabria [1467 ha and 231 ha, respectively (Istituto Nazionale di Statistica, 2000)] could be another argument for its ancient presence in these areas, even if no old historical citation exists. Considering the geographical origin of the 'Sangiovese' kin group and Italian grape history, Sicily and Calabria are likely areas where 'Sangiovese' was first grown, invalidating the autochthonous Etruscan hypothesis for 'Sangiovese' (Fregoni, 1991; Mainardi, 2001). Moreover, far southern Italy (called Enotria by Latin people) has been a legendary place of wine production since antiquity (Brun, 2004), justifying the exportation of cultivars to central and northern vineyards. Furthermore, since the 16th century, exchanges of cultivars between these regions have existed. For example, 'Vernaccia di Siracusa' N and B, probably originating from Syracuse in Sicily, were cultivated in Tuscany (Basso, 1982; Marescalchi and Dalmasso, 1937); similarly, 'Inzolia' B and 'Trebbiano toscano' B are currently common to both regions. The fact that Sicily is an island does not contrast with the successive migrations in the Italian peninsula up to Tuscany, because Sicily was frequently involved in Italian history. We do not know when 'Sangiovese' appeared in far southern Italy, but it was certainly before the citation of Soderini (1590) and after the beginning of viticulture in Calabria and Sicily. Because genetic structuring clustered 'Sangiovese' with a very large number of ancient Italian cultivars, and because the importance of sexual reproduction was demonstrated for grape (Bowers et al., 1999a), we suppose that 'Sangiovese' originated from spontaneous or voluntarily crossing, likely in southern Italy, and was transferred as a seed, like Criolla cultivars (Agüero et al., 2003), or by vegetative propagation. This suggests that 'Sangiovese' originated during a period of time in which cultural and technical methods allowed for sexual reproduction and for selection of seedling cultivars. We know that in the past, multicultivar vineyards provided the way of spontaneous crossings. In Europe, we estimate this period (the "Seedling Ages") to be from the beginning of viticulture in far southern Italy [10th century $\mathrm{BC}$ (Brun, 2004)] to the Middle Ages. 'Sangiovese' then spread to central Italy, Corsica, and Algeria, as revealed by synonyms.

\section{Literature Cited}

Adam-Blondon, A.-F., C. Roux, D. Claux, G. Butterlin, D. Merdinoglu, and P. This. 2004. Mapping 245 SSR markers on the Vitis vinifera genome: A tool for grape genetics. Theor. Appl. Genet. 109:1017-1027.

Agüero, C.B., J.G. Rodríguez, L.E. Martínez, G.S. Dangl, and C.P. Meredith. 2003. Identity and parentage of Torrontés cultivars in Argentina. Amer. J. Enol. Viticult. 54:318-321.

Aradhya, M.K., G.S. Dangl, B.H. Prins, J.-M. Boursiquot, M.A. Walker, C.P. Meredith, and C.J. Simon. 2003. Genetic structure and differentiation in cultivated grape, Vitis vinifera L. Genet. Res. 81179-192.

Basso, M. 1982. Agrumi, frutta e uve nella Firenze di Bartolomeo Bimbi pittore mediceo. Centro Nazionale per la Ricerca, Firenze, Italy.

Boselli, M. 2001. Il Sangiovese: Importanza e diffusione, p. 25-30. Proc. I International Symposium on 'Sangiovese'. Agenzia Regionale per lo Sviluppo e 1'Innovazione in Agricoltura, Firenze, Italy.
Bowcock, A.M., A. Ruiz-Linares, J. Tomfohrde, E. Minch, J.R. Kidd, and L.L. Cavalli-Sforza. 1994. High resolution of human evolutionary trees with polymorphic microsatellites. Nature 368:455-457.

Bowers, J.E., J.-M. Boursiquot, P. This, K. Chu, H. Johansson, and C.P. Meredith. 1999a. Historical genetics: The parentage of 'Chardonnay', Gamay, and other wine grapes of northeastern France. Science 285:1562-1565.

Bowers, J.E., G.S. Dangl, and C.P. Meredith. 1999b. Development and characterization of additional microsatellite DNA markers for grape. Amer. J. Enol. Viticult. 50:243-246.

Bowers, J.E., G.S. Dangl, R. Vignani, and C.P. Meredith. 1996. Isolation and characterization of new polymorphic simple sequence repeat loci in grape (Vitis vinifera L.). Genome 39:628-633.

Bowers, J.E. and C.P. Meredith. 1997. The parentage of a classic wine grape: Cabernet Sauvignon. Nat. Genet. 16:84-87.

Breviglieri, N. and E. Casini. 1964. Riordinamento ampelografico in Toscana. Vitigni ed uve da vino per i futuri impianti, p. 35-41. In: Accademia Italiana della vite e del vino (eds.). Atti, vol. 17. Treviso, Italy.

Brun, J.-P. 2004. Archéologie du vin et de l'huile. De la préhistoire à l'époque hellénistique. Editions Errance, Paris.

Calò, A., A. Scienza, and A. Costacurta. 2001. Vitigni d'Italia. Edagricole, Bologna, Italy.

Cavalli-Sforza, L. 1965. Analisi statistica per medici e biologi. Boringheri, Torino, Italy.

Crespan, M., A. Calò, A. Costacurta, N. Dilani, M. Giusti, R. Carraro, and R. Di Stefano. 2002. Ciliegiolo e Aglianicone: Unico vitigno direttamente imparentato col Sangiovese. Riv. Viticol. Enol. 2/3:3-14.

Dakin, E.E. and J.C. Avise. 2004. Microsatellite null alleles in parentage analysis. Heredity 93:504-509.

Dettweiler, E., A. Jung, E. Zyprian, and R. Töpfer. 2000. Grapevine cultivar Müller-Thurgau and its true to type descent. Vitis 39:63-66. Di Vecchi Staraz, M., T. Lacombe, V. Laucou, R. Bandinelli, D. Varès, M. Boselli, and P. This. 2006a. Studio sulle relazioni genetiche tra viti selvatiche e coltivate in Toscana. Proceedings of the II International Symposium on 'Sangiovese', Agenzia Regionale per lo Sviluppo e l'Innovazione in Agricoltura, Firenze, Italy, 17-18 Nov. 2004.

Di Vecchi Staraz, M., P. This, R. Bandinelli, V. Laucou, D. Varès, T. Lacombe, and M. Boselli. 2006b. Contributo alla caratterizzazione genetica di alcune varietà di $V$. vinifera $\mathrm{L}$. del germoplasma toscano. Proceedings of the II International Symposium on 'Sangiovese', Agenzia Regionale per lo Sviluppo el'Innovazione in agricoltura Firenze, Italy, 17-18 Nov. 2004.

Ewen, K.R., M. Bahlo, S.A. Treloar, D.F. Levinson, B. Mowry, J.W. Barlow, and S.J. Foote. 2000. Identification and analysis of error types in high-throughput genotyping. Amer. J. Hum. Genet. 67:727736

Filippetti, I., C. Intrieri, M. Centinari, B. Bucchetti, and C. Pastore. 2005. Molecular characterization of officially registered Sangiovese clones and of other Sangiovese-like biotypes in Tuscany, Corsica and Emilia-Romagna. Vitis 44:167-172.

Filippetti, I., C. Intrieri, O. Silvestroni, and M.-R. Thomas. 1999. Diversity assessment of seedlings from self-pollinated 'Sangiovese' grapevines by ampelography and microsatellite DNA analysis. Vitis 38:67-71.

Fregoni, M. 1991. Origines de la vigne et de la viticulture: Contribution des peuples antiques. Musumeci, Aosta, Italy.

Institut National de la Recherche Agronomique. 2004. Domaine de Vassal: Centre de resources génétiques de la vigne. 7 Sept. 2006. $<$ www.montpellier.inra.fr/vassal/collections/presentation.html $>$.

International Plant Genetic Resources Institute, Union internationale Pour les Obtentions Végétale, and Office International de la Vigne et du vin. 1997. Descriptors for grapevine (Vitis spp.). International Union for the Protection of New Varieties of Plants, Geneva, Switzerland; Office International de la Vigne et du Vin, Paris; and International Plant Genetic Resources Institute, Rome. 
Istituto Nazionale di Statistica. 2000. Quinto Censimento Nazionale dell'Agricoltura. Istituto Nazionale di Statistica, Rome.

Lacombe, T., J.-M. Boursiquot, V. Laucou, F. Dechesne, D. Varès, and P. This. 2007. Relationships and genetic diversity within the accessions related to 'Malvasia' held in the INRA grape germplasm repository at Domaine de Vassal. Amer. J. Enol. Viticult. 58:124-131.

Mainardi, G. 2001. Storia di un grande protagonista dell'enologia italiana: Il 'Sangiovese'. Proc. I International Symposium on 'Sangiovese'. Agenzia Regionale per lo Sviluppo e l'Innovazione in Agricoltura, Firenze, Italy. p. 17-23.

Marescalchi, A. and G. Dalmasso. 1937. Storia della vite e del vino in Italia. Vol. III. Arti grafiche Gualdoni, Milano, Italy.

Merdinoglu, D., G. Butterlin, L. Bevilacqua, V. Chiquet, A.-F. AdamBlondon, and S. Decroocq. 2005. Development and characterization of a large set of microsatellite markers in grapevine (Vitis vinifera L.) suitable for multiplex PCR. Mol. Breed. 15:349-366.

Ministère de l'agriculture et de la pêche. 2000. Recensement agricole 2000: La viticulture en France métropolitaine. Agreste: La statistique agricole. Ministère de l'agriculture et de la pêche, Service central des enquêtes et etudes statistiques (SCEES), Paris.

Pritchard, J.K., M. Stephens, and P. Donnelly. 2000. Inference of population structure using multilocus genotype data. Genetics 155:945-959.

Queller, D.C. and K.-F. Goodnight. 1989. Estimating relatedness using genetic markers. Evolution 160:1203-1215.

Racah, V. 1932. Pagine di viticoltura vissuta. Giunti, Firenze, Italy.

Rives, M. 1961. Bases genetiques de la selection clonale chez la vigne.

Ann. Amelioration Plantes 11:337-348.

Schaal, B.A., D.A. Hayworth, K.M. Olsen, J.T. Rauscher, and W.A. Smith. 1998. Phylogeographic studies in plants: Problems and prospects. Mol. Ecol. 7:465-474.

Scienza, A. 1993. Vigneti policlonali e valorizzazione della diversità dei vini. Vignevini 20:23-24.

Sefc, K.-M., F. Lefort, M.-S. Grando, K. Scott, H. Steinkellner, and M.-R. Thomas. 2001. Microsatellite markers for grapevine: A state of the art, p. 433-463. In: K.A. Roubelakis-Angelakis (ed.).
Molecular biology and biotechnology of grapevine. Kluwer, Amsterdam, The Netherlands.

Sestini, D. 1774. Memorie sui vini sicilmiani. Accademia dei Georgofili, Firenze, Italy.

Soderini, G. 1590. Coltivazione toscana delle viti e d'alcuni alberi. Giunti, Firenze, Italy.

This, P., A. Jung, P. Boccacci, J. Borrego, R. Botta, L. Costantini, M. Crespan, G.S. Dangl, C. Eisenheld, F. Ferreira-Monteiro, M.S. Grando, J. Ibanez, T. Lacombe, V. Laucou, R. Magalhaes, C.P. Meredith, N. Milani, E. Peterlunger, F. Regner, L. Zulini, and E. Maul. 2004. Development of a standard set of microsatellite reference alleles for identification of grape cultivars. Theor. Appl. Genet. 109:1448-1458.

This, P., T. Lacombe, and M.R. Thomas. 2006. Historical origins and genetic diversity of wine grapes. Trends Genet. 22:511-519.

Thomas, M.R. and N.S. Scott. 1993. Microsatellite repeats in grapevine reveal DNA polymorphisms when analysed as sequence-tagged sites (STSs). Theor. Appl. Genet. 86:985-990.

U.S. Department of Agriculture. 2006. Grape acreage report, 2005 California. 7 Sept. 2006. <www.nass.usda.gov/Statistics_by_State/ California/Publications/Fruits_and_Nuts/200603grpac.pdf $>$.

Vignani, R., J. Bowers, and C.P. Meredith. 1996. Microsatellite DNA polymorphism analysis of clones of $V$. vinifera 'Sangiovese'. Sci. Hort. 65:163-169.

Vignani, R., M. Scali, E. Masi, and M. Cresti. 2002. Genomic variability in Vitis vinifera L. 'Sangiovese' assessed by microsatellite and non-radioactive AFLP test. Electron. J. Biotechnol. 5:1.

Villifranchi, C.G. 1773. Oenologia Toscana o sia memoria sopra i vini ed in special modo toscani. Ciambiagi, Firenze, Italy.

Vouillamoz, J., D. Maigre, and C.P. Meredith. 2003. Microsatellite analysis of ancient alpine grape cultivars: Pedigree reconstruction of Vitis vinifera L. 'Cornalin du Valais'. Theor. Appl. Genet. 107:448454.

Vouillamoz, J., S. Imazio, M. Stefanini, A. Scienza, and M.S. Grando. 2006. Relazioni genetiche del Sangiovese. In: Proc. II International Symposium on 'Sangiovese', Agenzia Regionale per lo Sviluppo e l'Innovazione in Agricoltura, Firenze, Italy, 17-18 Nov. 2004. 